\title{
Possibility of Application of Extracellular Protease of the Micromycete Aspergillus ochraceus VKM F-4104D for Determination of the Protein C Content in Human Blood Plasma
}

\author{
A. A. Osmolovskiy ${ }^{a, *}$, A. V. Orekhova ${ }^{a, b}$, V. G. Kreyer ${ }^{a}$, N. A. Baranova ${ }^{a}$, and N. S. Egorov \\ ${ }^{a}$ Biological Faculty of Moscow State University, Moscow, 119234 Russia \\ ${ }^{b}$ Faculty of Fundamental Medicine of Moscow State University, Moscow, Russia \\ ${ }^{c}$ International Biotechnology Center of Moscow State University, Moscow, Russia \\ *e-mail: aosmol@mail.ru \\ Received October 11, 2017
}

\begin{abstract}
The protein C activator activity, determined in normal plasma by using A. ochraceus protease is comparable with the activity of a commercial protease analogue from the South American copperhead venom $\left(\right.$ Protac $\left.^{\circledR}\right)$. As in the case of Protac ${ }^{\circledR}$, the $A$. ochraceus protease can be used for protein $\mathrm{C}$ determination in plasma with its reduced content. Comparison of the activator protein $\mathrm{C}$ activity of $A$. ochraceus protease and the commercial analogue showed some excess of the activator activity of the fungal preparation, which may be a promising substitute for the snake activator in diagnostical kits for determining the protein $\mathrm{C}$ content in clinical laboratories.
\end{abstract}

Keywords: proteases of micromycetes, activators of protein C, diagnosis of protein C

DOI: $10.1134 /$ S1990750818020099

\section{INTRODUCTION}

Insufficiency of the anticoagulant protein content of plasma hemostasis, protein $\mathrm{C}$, is a serious risk factor for venous thrombosis; it leads to a high risk of thrombotic complications up to lethal outcomes. Reduction of its content is associated with deep vein thrombosis, pulmonary embolism, thrombophlebitis and disseminated intravascular coagulation. The content of this plasma protein less than $20 \%$ is incompatible with life $[1,2]$. At present, proteolytic enzymes obtained from the venom of South American copperhead Agkistrodon contortrix contortrix are used for determination of protein $\mathrm{C}$ content in blood plasma and the diagnostic preparation Protac ${ }^{\circledR}$ (Pentapharm, Switzerland) has been developed on this basis [3]. Protein $\mathrm{C}$ incubation with an activator from $A$. contortrix contortrix results in limited proteolysis and conversion of protein $\mathrm{C}$ into its active form, activated protein $\mathrm{C}$, which cleaves the specific chromogenic peptide substrate pGlu-ProArg-pNA(S-2366) with release of free pNA ( $p$-nitroaniline) and the pNA concentration is directly proportional to the concentration of protein $\mathrm{C}$ in an analyzed sample [4].

Recently, an extracellular protease, a protein $\mathrm{C}$ activator, produced by the microscopic fungus Aspergillus ochraceus VKM F-4104D [5, 6] has been discovered and studied. The study has shown that this enzyme has narrow substrate specificity; it does not hydrolyze most of chromogenic protease substrates. Comparison of the properties of the A. ochraceus protease and the enzyme from the Agk. contortrix contortrix snake venom revealed that they shared similar properties; however, the protease from the micromycete culture fluid was not glycosylated and was capable of hydrolyzing the chromogenic plasmin substrate [7]. In this regard, it is of great interest to explore the possibility of its application for determination of the plasma protein $\mathrm{C}$ content in comparison with the protease of the Protac ${ }^{\circledR}$ preparation.

\section{MATERIALS AND METHODS}

Protease-activators of protein $\mathrm{C}$ from culture liquid of $A$. ochraceus micromycete VKM F-4104D and the South American copperhead venom Protac ${ }^{\circledR}$, and lyophilized human blood plasma with different characteristics were used in the study (Renam, Russia): plasma with normal parameters of the hemostasis system, human blood plasma with artificially lowered parameters of the hemostatic system and human plasma with a reduced level of protein $\mathrm{C}$.

The protease from $A$. ochraceus VKM F-4104D was obtained by precipitating the proteins of the culture liquid [8] with ammonium sulfate (80\% saturation) in the cold $\left(4^{\circ} \mathrm{C}, 24 \mathrm{~h}\right)$, followed by centrifugation at $15000 \mathrm{~g}$, for $25 \mathrm{~min}$ at $4^{\circ} \mathrm{C}$. The sediment dis- 


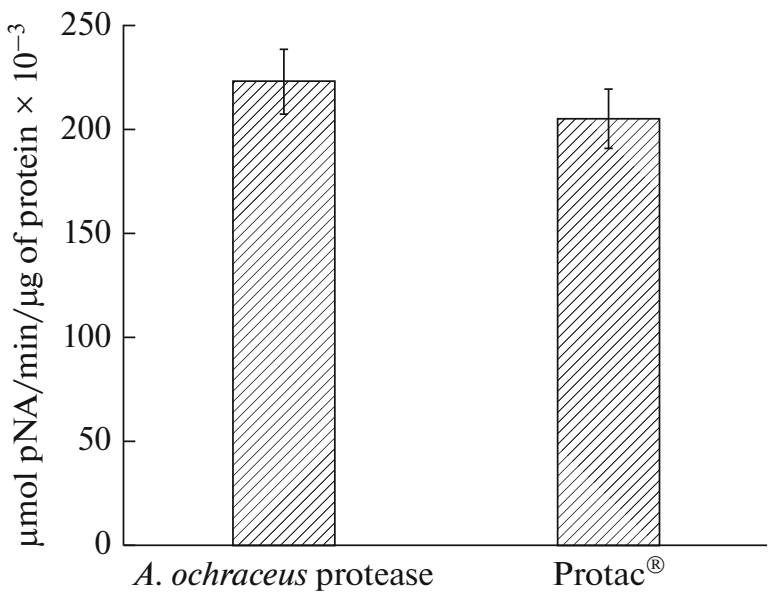

Fig. 1. Protein $\mathrm{C}$ activator activity of proteases Aspergillus ochraceus and Protac ${ }^{\circledR}$.

solved in a minimal volume of $0.005 \mathrm{M}$ Tris- $\mathrm{HCl}$ buffer, $\mathrm{pH} 8.2$, was dialyzed against the same buffer for $12 \mathrm{~h}$ at $4^{\circ} \mathrm{C}$. The dialyzed protein solution was centrifuged under the same conditions to remove the insoluble part of the precipitate, and then the supernatant proteins were separated by isoelectrofocusing on a $110 \mathrm{~mL}$ column (LKB, Sweden) in a sucrose density gradient of $0-40 \%$ by the Westerberg method $(800 \mathrm{~V}$, $4^{\circ} \mathrm{C}, 36 \mathrm{~h}$ ) [9], using LKB ampholins with a $\mathrm{pH}$ range of 4-9; the column content was collected in fractions of $1.5 \mathrm{~mL}$ by using a LKB fraction collector. Fractions with $\mathrm{pI}$ of 5.7-6.2 containing the desired protease were selected for the further work [2]. The homogeneity of the isolated protein was confirmed by denaturing polyacrylamide gel electrophoresis (the Laemmli method). Enzyme purification from ampholins without simultaneous concentration was performed by centrifuging samples $(500 \mu \mathrm{L})$ at $12400 \mathrm{~g}$ for $10 \mathrm{~min}$ in the Microcon Ultracel 30 membrane concentrators for Eppendorf (Millipore, USA). The supernatant was then decanted and the retentate collected in a new Eppendorf tube was centrifuged again $(1000 \mathrm{~g}, 1 \mathrm{~min})$ according to the manufacturer's instructions. In the retentate, the protein content and activator protein $\mathrm{C}$ activity were determined.
Protein concentration was determined spectrophotometrically by absorbance at $280 \mathrm{~nm}\left(\mathrm{~A}_{280}\right)$. A protein solution characterized by $\mathrm{A}_{280}$ (in a cuvette with a light path of $1 \mathrm{~cm}$ ) equal to 1.00 contained 1 optical unit (o.u., $\mathrm{A}_{280}$ ) in $1 \mathrm{~mL}$ [10].

The activity of protein $\mathrm{C}$ activator was determined by the modified Kreyer's method. Samples $(200 \mu \mathrm{L})$ containing A ochraceus or Protac ${ }^{\circledR}$ protein were preincubated with $50 \mu \mathrm{L}$ of plasma samples diluted two times with $0.05 \mathrm{M}$ Tris- $\mathrm{HCl}$ buffer, $\mathrm{pH} \mathrm{8.2,} \mathrm{at} 37 \pm$ $0.1^{\circ} \mathrm{C}$ for 5 min using a BioSan TS- 100 thermoshaker (Latvia). After the incubation for $5 \mathrm{~min}, 100 \mu \mathrm{L}$ of a chromogenic substrate S-2366 (pGlu-Pro-Arg-pNA, $0.5 \mathrm{mg} / \mathrm{mL}$ ) was added to the mixture and incubation continued for another $5 \mathrm{~min}$. The reaction was stopped by adding $200 \mu \mathrm{L}$ of $50 \%$ acetic acid. The amount of liberated pNA was measured on a Hitachi 200-20 spectrophotometer (Japan) at $405 \mathrm{~nm}$ [5].

\section{RESULTS AND DISCUSSION}

The $A$. ochraceus protease is of considerable interest as a possible active component of diagnosticums for protein $\mathrm{C}$ content determination. In this context, activity of this enzyme towards protein $\mathrm{C}$ was compared with the activity of the snake venom protease included in the Protac ${ }^{\circledR}$ (Fig. 1). Figure 1 shows that specific activity of the $A$. ochraceus protease is comparable with the activity of the snake activator and even slightly exceeds it.

The possibility of $A$. ochraceus protease applicability for diagnostics of plasma protein $\mathrm{C}$ was demonstrated using the reagents required by existing protocols. For this purpose, calibration graphs were constructed using lyophilized human blood plasma in various dilutions with parameters of the hemostasis system within the normal limits. Figure 2a shows the standard curve obtained by using the Protac ${ }^{\circledR}$ preparation as the active component of the diagnostic kit, which is used in clinical practice to determine the plasma protein $\mathrm{C}$ content. A similar calibration plot was obtained using $A$. ochraceus protease as an active component (Fig. 2b). It is seen that it is also linear, but differs in its equation from the calibration curve using

Table 1. Activator activity of a commercial diagnosticum and the Aspergillus ochraceus L-1 protease, determined in plasmas with reduced parameters of the hemostasis system

\begin{tabular}{l|c|c|c}
\hline \multirow{2}{*}{\multicolumn{1}{c|}{ Parameter }} & \multicolumn{3}{|c}{ Protein C content, \% } \\
\cline { 2 - 4 } & $\begin{array}{c}\text { according } \\
\text { to plasma passport }\end{array}$ & $\begin{array}{c}\text { determined } \\
\text { with protein C } \\
\text { activator (Protac }\end{array}$ & $\begin{array}{c}\text { determined } \\
\text { with Aspergillus } \\
\text { ochraceus protease }\end{array}$ \\
\hline $\begin{array}{l}\text { Normal plasma } \\
\text { Simulated pathological plasma (with artificially } \\
\text { reduced parameters of the hemostasis system) }\end{array}$ & $34 \pm 9$ & $85 \pm 3$ & $85 \pm 2$ \\
Plasma with a reduced level of protein C & $57 \pm 10$ & $32.7 \pm 5$ & $31.5 \pm 5$ \\
\hline
\end{tabular}


(a)

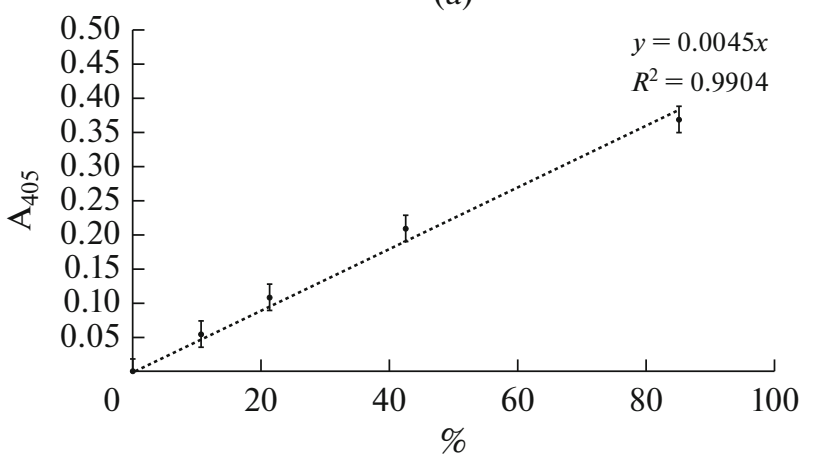

(b)

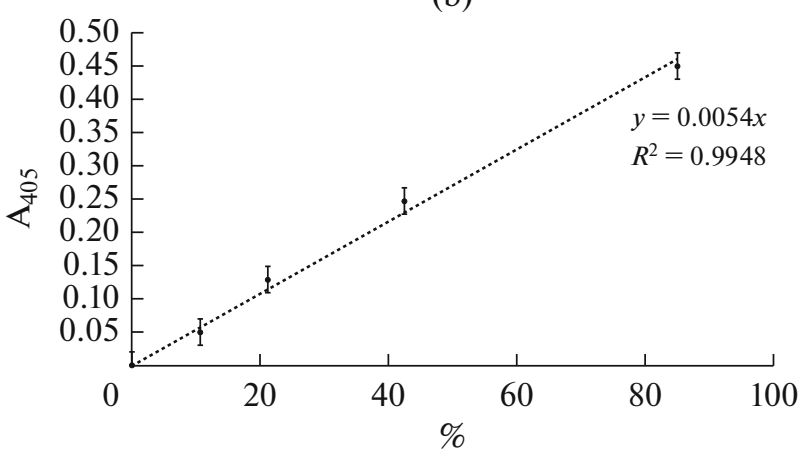

Fig. 2. (a) Calibration curve with lyophilized human blood plasma characterized by parameters of the hemostasis system within the normal limits (Protac ${ }^{\circledR}$ preparation, chromogenic substrate S-2366). (b) Calibration curve with lyophilized human blood plasma characterized by parameters of the hemostasis system within the normal limits (Aspergillus ochraceus L-1 protease, chromogenic substrate S-2366).

$\operatorname{Protac}^{\circledR}$ : the activity values versus the protein $\mathrm{C}$ concentration were somewhat higher. Thus, the dependence of the $A$. ochraceus protease activity towards protein $\mathrm{C}$ on the plasma concentration (protein $\mathrm{C}$ content) is concentration-dependent.

Verification of the applicability of the constructed calibration graphs for determination of the protein $\mathrm{C}$ content is possible by carrying out appropriate reactions using plasmas with an artificially reduced content of this component or its deficiency in it.

Table 1 summarizes data on determination the activator activity of $A$. ochraceus protease towards protein $\mathrm{C}$ in plasmas with different protein $\mathrm{C}$ contents in comparison with the $\operatorname{Protac}^{\circledR}$ preparation. Table 1 shows that the activator activity of the $A$. ochraceus protease is comparable to the activator activity of Protac $^{\circledR}$ towards $C$ protein. Comparison of results with passports of the plasma samples used in the work has shown that the level of plasma protein $\mathrm{C}$ was reliably detected by both snake venom protease and the A. ochraceus protease. The data obtained indicate that the $A$. ochraceus protease can be used as a component of a diagnostic kit for protein $\mathrm{C}$ determination in plasma samples of patients.

\section{CONCLUSIONS}

The study has shown that the activator activity of protein $\mathrm{C}$, determined in normal plasma by a standard procedure using $A$. ochraceus protease, is comparable with the activity of a commercial analogue, the Protac ${ }^{\circledR}$ preparation. The $A$. ochraceus protease can be used for protein $\mathrm{C}$ determination in plasmas with its reduced content similar to $\operatorname{Protac}^{\circledR}$. Comparison of the activity of $A$. ochraceus proteases and the preparation from the venom of South American copperhead showed a somewhat higher activator activity of the fungal preparation, which may be therefore considered as a promising substitute for the snake activator in diagnosticums for determining protein $\mathrm{C}$ contents in clinical laboratories.

\section{ACKNOWLEDGMENTS}

This work was supported by the Foundation for Assistance to Small Innovative Enterprises in Science and Technology (Agreement no. 7691GU2/2015).

\section{REFERENCES}

1. Griffin, J.H., Zlokovich, B.V., and Mosnier, L.O., Int. J. Hematol., 2012, vol. 95, no. 4, pp. 333-345. doi 10.1007/s12185-012-1059-0

2. Barranco-Medina, S., Murphy, M., Pelc, L., Chen, Z., Di Cera, E., and Pozzi, N., Scientific Reports, 2017, vol. 7, p. 44596. doi 10.1038/srep44596

3. Stoker, K., Fisher, H., Meier, J., Brogli, M., and Svedsen, L., Toxicon, 1987, vol. 25, no. 3, pp. 239-252.

4. Gempeler-Messina, P.M., and Müller, C., Toxin Rev., 2006, vol. 25, no. 4, pp. 335-349.

5. Osmolovskiy, A.A., Kreyer, V.G., Kurakov, A.V., Baranova, N.A., and Egorov, N.S., Appl. Biochem. Microbiol., 2012, vol. 48, no. 5, pp. 537-542.

6. Zvonareva, E.S., Osmolovskiy, A.A., Kreyer, V.G., Baranova, N.A., Kotova, I.B., and Egorov, N.S., Russ. J. Bioorg. Chem., 2015, vol. 41, no. 5, pp. 559-564. doi 10.7868/S0132342315050152

7. Osmolovskiy, A.A., Kreyer, V.G., Baranova, N.A., Kurakov, A.V., and Egorov, N.S., Appl. Biochem. Microbiol., 2015, vol. 51, no. 1, pp. 86-92. doi 10.7868/S0555109915010122

8. Osmolovskiy, A.A., Kreyer, V.G., Baranova, N.A., Kurakov, A.V., and Egorov, N.S., Appl. Biochem. Microbiol., 2013, vol. 49, no. 6, pp. 580-586. doi 10.7868/S0555109913060147

9. Vesterberg, O., Biochim. Biophys. Acta, 1972, vol. 257, no. 1, pp. 11-19.

10. Gertler, A. and Trop, M., Eur. J. Biochem., 1971, vol. 19, no. 1, pp. 90-96.

Translated by A. Medvedev 